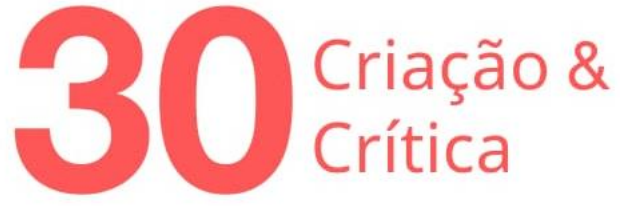

\section{AS PALAVRAS DANÇANTES DE BARTHES}

\author{
Julia Bunemer Nojiri ${ }^{1}$
}

Resumo: Profundamente tocado pelos escritos do filósofo que declarou a morte de Deus, Barthes analogamente declara a morte do autor; dada a impossibilidade de conhecimento claro e distinto, a exposição de sua contra-teoria do texto deve ser condizente: fragmentada e exposta através de metáfora. Assim, este artigo tem por mote abrir caminho para uma aproximação entre a dança e a escritura de Barthes, mostrando a necessidade de um estilo de exposição em que conceitos são metaforizados e articulados para se movimentar, impulsionados pelo que se afirma no lugar da ciência: o prazer. Para tanto, será revista a influência de Nietzsche sobre Barthes, de modo a evidenciar a necessidade de uma tal escrita, que culminará em O prazer do texto barthesiano, marco na vida escritural de Barthes em que teoria e sensualidade se confundem, como aqui se quer mostrar.

PALAVRAS-CHAVE: Barthes, Nietzsche, prazer, metáfora, dança.

\section{BARTHES’ DANCING WORDS}

ABSTRACT: Deeply touched by the writings of the philosopher who claimed the death of God, Barthes likewise claims the death of the author; due to the impossibility of clear and distinct knowledge, his counter theory of the text exposition is to be befitting: fragmented and exposed through metaphor. Thus this article aims to make way to an approach between dance and Barthes' writing, pointing out the necessity of an exposition style in which concepts are metaphorized and articulated to move, pushed by what is to be asserted instead of science: pleasure. Therefore Nietzsche's influence upon Barthes will be reviewed, so it can be evidenced the necessity of such a writing, that will climax in Barthes' The pleasure of the texte, a landmark in his writing life in which theory and sensuality are confounded, as we aim to reveal here.

KEYwORDS: Barthes, Nietzsche, pleasure, metaphor, dance.

Para que possamos investigar $O$ prazer do texto dando especial atenção à maneira barthesiana de escrever, aqui será revista a influência de Nietzsche não apenas na obra supracitada, mas também em escritos que o apontam como uma constante influência no pensamento e inspiração na escrita. Uma vez que em tal obra Barthes abandona a semiologia, com a qual vinha construindo seu percurso intelectual, para adentar uma nova fase - a da escrita pessoal, "caracterizada pela aliança da inteligência crítica com a sensualidade verbal" (PERRONE-MOISÉS, 2010), buscaremos compreender do que se trata essa "escrita pessoal", bem como mostrar o papel fundamental dessa "sensualidade verbal" de que fala Perrone-Moisés, traçando, por assim dizer, uma genealogia da escrita barthesiana.

\footnotetext{
${ }^{1}$ Graduanda em Filosofia com pesquisa em andamento no departamento de Letras Modernas na Universidade de São Paulo. Bolsista do CNPq. julia.nojiri@usp.br.
} 


\section{Criação \&}

Tarefa essa poderia se mostrar inviável se pretendêssemos rastrear as citações de Nietzsche e de outros autores que influenciaram Barthes, visto que o próprio é notório por descontextualizar suas citações ou fazê-las indiretamente, como ele mesmo o diz:

Saboreio o reino das fórmulas, a inversão das origens, a desenvoltura que faz com que o texto anterior venha do texto ulterior. Compreendo que a obra de Proust é, pelo menos para mim, obra de referência, [...] isso não quer dizer de modo algum que eu seja um "especialista" em Proust: Proust é o que me vem, não o que eu chamo; não é uma "autoridade"; simplesmente uma lembrança circular. E é justamente isso o intertexto: a impossibilidade de viver fora do texto infinito - seja esse texto Proust, ou o jornal cotidiano, ou a tela da televisão: o livro faz o sentido, o sentido faz a vida (BARTHES, 1973b, p. 59)2.

Ora, por tudo o que Barthes diz acima, se quisermos recuperar as influências, aquilo que vem ao autor, para melhor compreendermos sua forma de escrever, é necessário que investiguemos "a desenvoltura que faz com que o texto anterior venha do texto ulterior". Isso quer dizer que para que possamos investigar Barthes de modo barthesiano, teremos que revisitar toda uma tradição do pensamento que será absorvida por Barthes e que, de modo análogo, o envolverá. Se, como o próprio diz "o livro faz o sentido, o sentido faz a vida", faz-se necessário entendermos o motivo de tal inversão em "livro", "sentido" e "vida", para que enfim seja possível mostrarmos como a não realização do projeto ficcional empreendido por Roland Barthes não é fruto do fracasso ou acaso, mas sim uma postura crítica de um autor cuja linguagem é, ao seu modo, herdeira de Sócrates, Pascal e Nietzsche, e que em O prazer do texto ganha toda sua potência.

Vejamos, então, o que Barthes diz sobre suas próprias influências.

Em sua obra Roland Barthes por Roland Barthes, o autor divide sua vida escritural em 5 fases:

\footnotetext{
2 "Je savoure le règne des formules, le renversement des origines, la désinvolture qui fait venir le texte antérieur du texte ultérieur. Je comprends que l'œuvre de Proust est, du moins pour moi, l'œuvre de référence, [...] cela ne veut pas du tout dire que je sois un 'spécialiste' de Proust: Proust, c'est ce qui me vient, ce n'est pas ce que j'appelle; ce n 'est pas une " autorité"; simplement un souvenir circulaire. Et c'est bien cela l'inter-texte: l'impossibilité de vivre hors du texte infini — que ce texte soit Proust, ou le journal quotidien, ou l'écran télévisuel : le livre fait le sens, le sens fait la vie". Tradução da autora.
} 


\section{$30_{\substack{\text { critica } \\ \text { criazo \& }}}$}

Quadro 1 - Vida escritural de Roland Barthes

\begin{tabular}{|c|c|c|}
\hline Intertexto & Gênero & Obras \\
\hline (Gide) & (desejo de escrever) & - \\
Sartre & mitologia & O grau zero \\
Marx & social & Escritos sobre o teatro \\
Brecht & & Mitologias \\
Saussure & semiologia & Elementos de semiologia \\
Sollers & Sistema da moda \\
Julia Kristeva & & S/Z \\
Derrida Lacan & & Sade, Fourier, Loyola \\
(Nietzsche) & O império dos signos \\
& & O prazer do texto \\
& & R. B. por ele mesmo \\
\hline
\end{tabular}

Fonte: Barthes (2003, p. 162).

Vale notar que sua primeira e sua última fases são marcadas, entre parênteses, por Gide e Nietzsche. Última, pois o autor morre cinco anos após sua publicação (aqui não se trata do famoso texto sobre a morte do autor, mas do óbito de Barthes em 1980, causado por atropelamento ou suicídio). Quanto ao motivo dos mencionados parênteses, isso ainda é fonte de especulação, mas é sabido que muito de seu contato com Nietzsche se deu através de Gide, grande leitor do filósofo alemão (WELLER, 2019). Assim, temos na tabela de Barthes, na condição de última (e velada) referência, Nietzsche, sendo seu gênero "moralidade" e obras correspondentes $O$ prazer do texto e Roland Barthes por Roland Barthes.

Apesar de ser um escritor de vasta obra crítica, ele jamais escreveu seu grande romance, Vita Nova: morreu às vésperas de sua redação. Mas, como coloca Pino (2010, p. 102), "a ausência aparente da escrita, a negação da escrita e a morte intencional da escrita faziam parte do projeto de Barthes". Desse modo, olhemos para o que o autor de fato escreveu, La préparation du roman, curso que Barthes ministrou no Collège de France entre 1978 e 1980, do qual seu romance não escrito também era tema.

A respeito da preparação do romance, em aula do dia 9 de fevereiro de 1980, Barthes diz, no capítulo intitulado "Du démarrage au travail", fragmento "Programmation", que tentará dizer onde está a dificuldade em se passar de um projeto retido à sua realização - e que a dificuldade está justamente na "programação", ou seja, em dúvidas como "o que farei amanhã?", "o que farei em geral?", "o que vou escrever?", "por onde vou começar?". Apesar de aparentar ser 


\section{Criação \&}

pragmático nessas citações, algumas páginas adiante o problema se mostra mais profundo: "terei tempo de acabar minha obra antes de morrer? De outro modo, terei tempo de realizar a forma prevista antes que eu mesmo mude?"3 (BARTHES, 2015, p. 794). Apontando para um tipo de problema einsteiniano, acusa-se um paradoxo de relativização em que "a não identidade do eu deve produzir um objeto definido pela identidade" ${ }^{4}$ (BARTHES, 2015, p. 794): eis a contradição do sujeito fragmentado, descentrado, que culmina em "A morte do autor" (o texto) que deve escrever - ele é paralisado pela dúvida.

Contudo, Barthes segue escrevendo e tem solução para pelo menos um tipo de problema ligado à programação: uma proposta de Valéry, que a divide em dois tipos, a saber: a programação por lógica, por aquilo que é devido, uma ordem das razões, que costuma ser a mais frequente; e a programação "pela mobília de uma grande forma fantasiada ('imaginária') e é nisso, portanto, uma atividade mais estética do que lógica (que se pareceria mais com a de um pintor ou em todo caso de um grafista oriental que mobília um espaço)" ${ }^{2}$ (BARTHES, 2015, p. 795).

Mas isso dificilmente poderia ser uma solução no sentido que Barthes a buscava, pois, justificando-se com o fragmento 757 pascaliano das Pensées, "a última coisa que se encontra ao se fazer uma obra é saber qual se deve colocar no começo"6 (PASCAL, 2000, p. 499), ele explicita que o problema é insolúvel em seus termos, visto que só se saberia por onde começar uma obra após tê-la acabado, tornando-se assim a programação impossível. Pascal, por sua vez, conta-nos como escreve em seu fragmento 472 :

Escreverei aqui meus pensamentos sem ordem e não, talvez, numa confusão sem desígnio. Essa é a verdadeira ordem, que sempre marcará meu objeto pela própria desordem. Estaria honrando demais meu assunto se eu o tratasse com ordem, já que quero mostrar que ele é incapaz disso (PASCAL, 2000, p. 335)

E seu motivo para tanto no fragmento 280 :

\footnotetext{
3 "Aurai-je le temps de finir mon livre avant de mourir? Autremant dit, aurai-je le temps de realizer la forme prevue avant que moi-même je ne change?". Tradução da autora,

4 "La non-identité du moi doit produire un objet défini par l'identité". Tradução da autora.

5 "Par meublement d'une grande forme fantasmée ('imaginaire') et c'est donc là une activité plus esthétique que logique (qui ressemblerait à celle d'un peintre ou en tout cas d'un graphiste oriental qui meuble un espace)". Tradução da autora.

6 "La dernière chose qu'on trouve en faisant un ouvrage, est de savoir celle qu'il faut mettre la première". Tradução da autora

7 “J'écrirai ici mes pensées sans ordre et non pas peut-être dans une confusion sans dessein. C'est le véritable ordre et qui marquera toujours mon objet par le désordre même. Je ferai trop d'honneur à mon sujet si je le traitais avec ordre puisque je veux montrer qu'il en est capable". Tradução da autora
} 


\section{Criação \&}

O coração tem sua ordem, o espírito tem a sua, que é por princípio e demonstração. O coração tem uma outra. Não se prova que se deve ser amado ao expor com ordem as causas do amor; isso seria ridículo $(2000 \text {, p. 204) })^{8}$.

O problema de fundo de Pascal remonta à tradição de pensamento filosófico que tem consequências drásticas para a linguagem: uma concepção de transcendência criacionista em que se teria um constante espaço entre criador e criatura. Isto é, Deus é diferenciado do indivíduo por gênero, número e grau, criandose assim um abismo intransponível entre eles - sendo um de seus desdobramentos a incompreensibilidade da natureza divina (como pode o indivíduo, finito, compreender a Deus, infinito?) e uma linguagem que opera na falta: é consequência de não se estar na presença de Deus (da coisa em si por excelência, do grande significado) que se dá a origem do significante.

Assim, se do lado de Pascal sua exposição fora de ordem se faz absolutamente necessária por Deus ser incompreensível em sua plenitude à razão humana, não sendo possível se demonstrar sua existência, mas apenas versar sobre ela, rendendo assim a própria ordem em ordem própria, do lado de Barthes se pode dizer o mesmo: tocado pela morte de Deus e da verdade pelas mãos de Nietzsche (como será apresentado adiante), era-Ihe preciso não escrever, mas versar sobre a escritura e assim escrever, fazendo o significante girar em torno de si mesmo.

Entretanto, aqui é devido explicitarmos uma nuance de grandes consequências: tal escritura não se trata de metalinguagem que tem por objetivo um saber científico, da capacidade da linguagem de se replicar para se explicar, como também será explicitado adiante, mas sim de um novo tipo de escrita em si mesma que não visa outra coisa senão a si: ela não se explica, não se desdobra, mas se movimenta em círculos, é tautológica.

Ora, contra o espaço entre o criador e a criatura - no caso de Barthes, entre a vida e a obra -, em seu curso sobre a preparação do romance ele diz que a solução para apaziguar tal embate é fazer de sua vida uma obra; e que para tanto há uma forma sem mediação, a saber, o diário (BARTHES, 2015). Em razão disso, com a morte do autor (o texto), a nova crítica acabou por recalcá-lo, o que só poderia ser desfeito com o retorno à biografia (BARTHES, 2015). Sobre isso, vale notar: ao aproximar a morte do recalque, Barthes indica que o autor não foi de fato morto, mas antes colocado num estado de silenciamento, tendo assim desenvolvido uma neurose que o impedia de escrever; não à toa, ele escreve Roland Barthes por Roland Barthes, revisita e ressignifica sua história.

\footnotetext{
8 "Le cœur a son ordre, l'esprit a le sien qui est par principe et démonstration. Le cœur en a un autre. On ne prouve pas qu'on doit être aimé en exposant d'ordre les causes de l'amour; cela serait ridicule". Tradução da autora.
} 


\section{Criação \&}

Ainda na mesma aula, Barthes diz que tal retorno, para ele, se deu em sua obra $O$ prazer do texto, com o abalo do supereu teórico, com o retorno dos textos amados, identificando aí um "desrecalque" do autor, o momento em que se permitiu ao eu falar um pouco, ao invés de sempre o supereu e o isso, de modo que teríamos nesse processo de libertação um modo de se "reagir contra o frio das generalizações, coletivizações, gregarizações e de colocar de volta na produção um pouco de afetividade 'psicológica"'? (BARTHES, 2015, p. 638).

Contra o frio, Barthes retorna aos "textos amados", dando logo o exemplo do Diário de Gide, sobre o qual ele tem dificuldade para explicar seu amor (coisa já prevista pelo fragmento 280 pascaliano), dizendo que lá aparece um autor que não é uma testemunha, mas um "ator de escritura", sendo "sem dúvida o Diário que dá o sentido do conjunto-Gide: ele faz precisamente um conjunto criativo de Vida + Obra; [...] a vida se deixa ler como inteiramente dirigida em direção à constituição da obra"10 (BARTHES, 2015, p. 640).

Isso quer dizer que Gide não só lhe despertou o desejo de escrever, como permitiu-lhe redescobrir seu estilo, visto que o mencionado Diário é notório justamente por seu embaralhamento entre obra e vida e por sua escrita fragmentada (vide o estilo de Roland Barthes por Roland Barthes), cujo propósito é, segundo Barthes tratando de Gide, evitar que o fechemos num "sistema" (WELLER, 2019, p. 228), o que evidentemente se aplica à sua própria forma de escrever sobre si mesmo, o que faz barrar qualquer possibilidade de se fazer do autor um objeto científico.

Cumpre dizer que tal estilo fragmentado se faz presente em outras obras de Gide, especialmente no que diz respeito à impossibilidade de uma plena compreensão racional, o que é evidenciado pela própria experiência de leitura do romance gideano, em que se transforma o sentido da obra à medida que se lê - é o caso de seu romance A porta estreita, em que o leitor tem acesso apenas ao fim ao diário da personagem morta, dando-se assim sentido à obra-, especialmente ao se tratar de sua leitura de Pascal:

Tanta grandiloquência surpreende, e tanto esforço; e para provar tão pouco. Eu me pergunto às vezes se sua entonação patética não é antes o efeito da dúvida que da fé. A fé perfeita não tem tantas lágrimas nem tremores em sua voz ${ }^{11}$ (GIDE, [s. d.], p. 155).

E então o fragmento transcrito pelo protagonista do diário de sua amada:

\footnotetext{
9 "De réagir contre le froid des généralisations, collectivisations et de remettre dans la production intellectuelle un peu d'affectivité 'psychologique'". Tradução da autora.

10 'Acteur d'écriture';'C'est sans doute le Journal qui donne à lire comme tout entière dirigée vers la constitution de l'œuvre'". Tradução da autora

11 "Tant de grandiloquence étonne, et tant d'effort; et pour prouver si peu. Je me demande parfois si son intonation pathétique n'est pas l'effet plutôt du doute que de la foi. La foi parfait n'a pas tant de larmes ni de tremblement dans la voix". Tradução da autora
} 


\section{Criação \&}

Nós falamos de Pascal... O que eu pude lhe dizer? Que afirmações vergonhosas, absurdas! Se eu já sofria ao dizê-las, esta noite eu me arrependo disso como que de uma blasfêmia (GIDE, [s. d.], p. 200) $)^{12}$.

No romance gideano, cuja epígrafe traz um versículo do Evangelho de Lucas que o nomeia (capítulo 13, versículo 24: "Esforçai-vos para entrar pela porta estreita"), temos uma personagem que busca se afastar do protagonista, e por isso dá falso testemunho, uma vez que acredita que não devem ficar juntos nesta vida, mas sim reencontrar seu amor junto a Cristo na eternidade. Gide, grande leitor de Nietzsche, assim se aproxima dele, que, subvertendo o Evangelho, dizia: "A antítese é a porta estreita que o erro mais gosta de usar para se introduzir na verdade" (NIETZSCHE, 2005b, p. 124).

Nietzsche, cuja família era extremamente religiosa (neto de pastores), não apenas detinha grande conhecimento das Escrituras, como também frequentemente as subvertia em sua obra, com o propósito de expor a ilusão de verdade que traziam em seu bojo, clamando que da materialidade de um som não se pode extrair uma verdade, pois nada garante a estabilidade do significado de um termo (ele era filólogo, estudava justamente a variação de significância das palavras ao longo da história), tornando-se assim qualquer raciocínio lógico ilegítimo de antemão:

Armamos para nós um mundo em que podemos viver - ao admitirmos corpos, linhas, superfícies, causas e efeitos, movimento e repouso, forma e conteúdo: sem esses artigos de fé, ninguém toleraria agora viver! Mas com isso não são nada de demonstrado. A vida não é argumento; entre as condições da vida poderia estar o erro (NIETZSCHE, 2014, p. 210).

Autor de $O$ anticristo, ele tinha uma relação conflituosa com Pascal: ora rebaixava-o, ora enaltecia-o dizendo ser ele o único cristão lógico, isto é, o alemão via no francês coerência e autenticidade por ter caminhado na contramão da ordem das razões cartesiana, afirmando-se a impossibilidade de uma demonstração lógica - que ficou conhecida como o "suicídio da razão" de Pascal (NIETZSCHE, 2005a, p. 48).

E não raro o proclamador da morte de Deus reconhece o legado do suicida da razão, tendo até mesmo escrito em rascunhos de sua autobiografia Ecce Homo que "o anticristão mesmo é a lógica necessária da evolução de um cristão verdadeiro, em mim o cristianismo se supera a si mesmo" (NIETZSCHE apud LEBRETON, 2018, p. 45). Destarte, o anticristão é em muito herdeiro do conteúdo do pensamento pascaliano, bem como de sua forma fragmentada de escrever, consequência última de uma verdade indemonstrável (no caso de Pascal), ou do fim da verdade, como é o caso de Nietzsche:

\footnotetext{
12“Nous avons parlé de Pascal... Qu'ai-je pu lui dire? Quels honteux, absurdes propos! Si je souffrais en les disant déjà, ce soir je m'en repens comme d'un blasphème". Tradução da autora.
} 


\section{Criação \&}

Mas, e se precisamente isso [a verdade ser divina] se tornar cada vez mais desacreditado, se nada mais se demonstrar como divino, que não seja o erro, a cegueira, a mentira - se Deus mesmo se demonstrar como nossa mais longa mentira? (NIETZSCHE, 2014, p. 220).

Assim, em certo sentido, é possível aproximarmos a morte da razão pelas mãos de Pascal da morte de Deus pelas mãos de Nietzsche - e analogamente da do autor, pelas mãos de Barthes, pois, do mesmo modo que o objeto de Pascal se mostrava indemonstrável (culminando numa ordem própria e fragmentada), o que se tem em Barthes é um novo modo de exposição que clama o fim da possibilidade de certeza interpretativa e, portanto, da ciência - o que é em muito herdeiro do pensamento nietzschiano. Não coincidentemente, Nietzsche não apenas marca a fase final de Barthes, como é uma das maiores referências teóricas de O prazer do texto (WELLER, 2019), em que Barthes dá adeus à assertividade científica ao deixar o eu falar - afirmando sua subjetividade, expressando-se por metáfora.

O que é a verdade, portanto? Um batalhão móvel de metáforas, metonímias, antropomorfismos, enfim, uma soma de relações humanas, que foram enfatizadas poética e retoricamente, transpostas, enfeitadas, e que, após longo uso, parecem a um povo sólidas, canônicas e obrigatórias (NIETZSCHE, 2014, p. 66).

O fim da verdade coincide com o fim do autor do mesmo modo que a forma de demonstração canônica deve ser deixada para trás - é preciso que se escreva em fragmentos e fazendo uso de metáfora em dois sentidos: é necessário que a forma da (não) demonstração acompanhe o que ela (não) demonstra, bem como isso é preciso no sentido de acuidade, dado que é a forma mais autêntica de se expor uma (não) teoria do texto que nunca coincide com a verdade; é um sentido em que é preciso ser tautológico, de modo que se tem em Barthes um uso absolutamente coerente da linguagem (muito inspirado em Nietzsche):

É a linguagem a expressão adequada de todas as realidades? Somente por esquecimento pode o homem alguma vez chegar a supor que possui uma "verdade" [...] Se ele não quiser contentar-se com a verdade em forma de tautologia, isto é, com os estojos vazios, comprará eternamente ilusões por verdades (NIETZSCHE, 2014, p. 64).

Temos, dessa maneira, mais um sentido em que Barthes não queria escrever, circunscrever, mas tinha antes a intenção de libertar o texto de seu significado transcendental, logo, de minar as possibilidades de um apontamento para fora do texto que pudesse esclarecê-lo, dar fim à metalinguagem e ao saber científico. 


\section{Criação \&}

Citando Nietzsche, Barthes diz que é devido abalar a verdade (BARTHES apud WELLER, 2019) e, no lugar disso, afirmar o prazer do texto.

Mas então, como the será possível escrever sobre o prazer? Nietzsche responde:

Quem antes aprendia a escrever bem numa língua moderna, devia tal habilidade a esse exercício (hoje temos que obrigatoriamente frequentar os antigos franceses); mais ainda: esse alguém obtinha noção da majestade e dificuldade da forma, e preparava-se para a arte pela única via correta - a prática (NIETZSCHE, 2005b, p. 128).

Ademais, isso quer dizer que uma tal contra-teoria do texto, uma afirmação do prazer no lugar da ciência, não se poderia dar senão por uma prática:

Que relação pode haver entre o prazer do texto e as intuições do texto? Muito fraca. A teoria do texto postula o gozo, mas ela tem pouco futuro institucional: o que ela funda, seu feito exato, sua assunção, é uma prática (a do escritor), de modo algum uma ciência, um método, uma pesquisa, uma pedagogia; devido a seus próprios princípios, essa teoria só pode produzir teóricos ou praticantes (escreventes), de modo algum especialistas (críticos, pesquisadores, professores, estudantes) ${ }^{13}$ (BARTHES, 1973b, p. 95, grifos nossos).

Ou seja, contra a metalinguagem, contra a assertividade científica, Barthes toma a escritura como prática, como um exercício de prazer. Como coloca Pino, é com uma nova forma de escrever que se soluciona a crise enfrentada pelo autor, em que se opera uma mudança de filiação: do pesquisador que busca novas propostas intelectuais com referências críticas (especialmente na fase 3), ao escritor que, com referências literárias, busca "uma nova forma de escrever e de se posicionar na sociedade" (PINO, 2019, p. 831).

Isso quer dizer que apesar de Barthes (como indica Sollers, seu amigo próximo e uma de suas referências na fase 4) ter sido um grande leitor de Nietzsche e de sempre tê-lo citado (WELLER, 2019), é apenas em sua última fase que o alemão é referenciado. Ademais, se é com Gide que se inaugura seu desejo de escrever, é com Nietzsche que a escrita é redescoberta e a "moralidade" (seu gênero correspondente) ressignificada. Referência essa, aliás, que Barthes chama de

\footnotetext{
13 "Quel rapport peut-il y avoir entre le plaisir du texte et les institutions du texte? Très mince. La théorie du texte, elle, postule la jouissance, mais elle a peu d'avenir institutionnel: ce qu'elle fonde, son accomplissement exact, son assumption, c'est une pratique (celle de l'écrivain), nullement une science, une méthode, une recherche, une pédagogie; de par ses principes mêmes, cette théorie ne peut produire que des théoriciens ou des praticiens (des scripteurs), nullement des spécialistes (critiques, chercheurs, professeurs, étudiants)". Tradução da autora.
} 


\section{Criação \&}

"intertexto", algo que não se trata necessariamente de um "campo de influências; é antes uma música de figuras, de metáforas, de pensamentos-palavras" (BARTHES, 2003, p. 162).

Com efeito, dada tal acepção de "intertexto" (muito nietzschiana em seu léxico), pode-se dizer que colocar Nietzsche entre parêntesis é na verdade uma atitude muito nietzschiana, em que o intertexto não é uma referência teórica, mas sim prática que une metáforas, símbolos, pensamentos e palavras. Ou, como coloca Barthes em O prazer do texto, a despeito do intertexto: "não é uma 'autoridade'; simplesmente uma lembrança circular"14 (BARTHES, 1973b, p. 59).

Quanto ao gênero "moralidade", ao qual Barthes aponta em sua tabela de fases, ele diz: "deve ser entendida como exato contrário da moral (é o pensamento do corpo em estado de linguagem)" (BARTHES, 2003, p. 162).

Novamente mais nietzschiano do que citando Nietzsche, Barthes acena a uma "lembrança circular", que aqui será retomada. Como coloca Weller (2019), tal concepção de moralidade tem suas raízes nos escritos do filósofo alemão, pois, em seu Le lexique de l'auteur, Barthes aponta para o que o teria inspirado os escritos postumamente publicados de Nietzsche: "Considero a moralidade grega 'nós poderíamos talvez acrescentar: a asiática' como a mais alta que já existiu; o que me prova isso é que ela levou ao seu apogeu a expressão corporal. Mas a moralidade em que penso é a efetiva do povo, não a dos filósofos" ${ }^{15}$ (NIETZSCHE apud BARTHES, 1973a, p. 59-60).

É evidente que o que se tem aqui é uma inversão, uma subversão do que normalmente se toma por moralidade, ou seja, a prática cultural socialmente aceita por um povo, os bons costumes. O que Nietzsche entende por moralidade também é uma prática cultural, mas não moral no sentido pudico do termo, mas antes como o costume de se exaltar o corpo, hábito comum entre os gregos. Mais do que isso: a moral, nesse outro sentido de bons costumes, é antes algo que deve ser combatido, uma vez que ela é maléfica à afirmação dos instintos humanos mais viscerais, ao corpo, enfim, à vida.

A própria moral - como? A moral não seria uma "vontade de negação da vida", um secreto instinto de aniquilação, um princípio de ruína, apequenamento, calúnia, um começo do fim? E, em consequência, o perigo entre os perigos?... Foi contra a moral que se voltou então, com este livro questionável, o meu instinto, como instinto que fala em favor da vida, e inventou uma doutrina e avaliação da vida fundamentalmente oposta, puramente artística, anticristã. Como denominá-la? Como filólogo e homem das palavras eu a batizei, não

\footnotetext{
14 “Ce n'est pas une 'autorité'; simplement un souvenir circulaire”. Tradução da autora.

15 “Je considère la moralité grecque 'nous pourrions peut-être ajouter: l'asiatique' comme la plus haute qui ait été jamais; ce qui me le prouve, c'est qu'elle a porté à son comble l'expression corporelle. Mais la moralité à laquelle je pense est la moralité effective du people, non celle des philosophes”. Tradução da autora.
} 


\section{Criação \&}

sem alguma liberdade - pois quem saberia o nome correto do Anticristo? - com o nome de um deus grego: eu a chamei dionisíaca (NIETZSCHE, 2020, p. 15).

E assim é possível que se resolva o problema do espaço criado pela criação transcendente; não mais em busca de redenção junto a Cristo, deve-se retornar à uma existência impulsionada pela arte que se vive por si mesma, que realiza a divindade nesta vida:

Cantando e dançando se manifesta o ser humano, como membro de uma comunidade superior; ele desaprendeu de andar e de falar e está em vias de ascender pelos ares a dançar. [...] ele se sente deus, agora caminha encantado e elevado, como via os deuses andarem nos seus sonhos. O ser humano não é mais artista, tornou-se obra de arte (NIETZSCHE, 2020, p. 25).

Desse modo, tal doutrina, tal modo de viver deve ser, como diz o autor, dionisíaco, porque é esse o da desmedida, da embriaguez, da dissolução da noção de indivíduo, dos prazeres corporais, que revelam o ser humano em estado bruto, contra a falsidade e dissimulação que iludem àqueles que fazem ciência. Se a ordem, as regras, não passam de palavras, e as palavras não têm sentido estável, nada podem de fato dizer: é impossível que se faça ciência. Portanto, é a expressão do corpo a mais autêntica possível - é apenas assim que se pode tangenciar a verdade, visto que adentrá-la não é jamais possível (ela sequer existe!). E eis aqui o equivalente à expressão corporal dionisíaca em forma de texto: palavras que dançam.

Um pouco de sabedoria é possível; mas esta bem-aventurada certeza encontrei em todas as coisas: elas ainda preferem - dançar com os pés do acaso (NIETZSCHE, 2018, p. 159-160).

Se são esses os intertextos tomados por Barthes, não é de se surpreender que ele tenha pensado na fragmentação do texto para combater a falsa ideia de estabilidade construída pelo discurso científico (WELLER, 2019). O próprio Barthes, escrevendo sobre escrever sobre o prazer, diz: "não posso senão girar em torno de tal assunto" (BARTHES, 1973b, p. 56) ${ }^{16}$. Ou seja, se as palavras giram em torno de si mesmas, que deem piruetas: eis um modo de desestabilizá-las, transmutar a linguagem do corpo para o texto - e de dar prazer, elemento que possibilita a leitura, religa o leitor ao texto. É preciso metaforizar, dar movimento às palavras.

Além disso, tal modo de pensar, que coincide com um modo de exposição, é uma libertação do ponto de vista da moral (tanto dos bons costumes quanto da

16 "Je ne puis que tourner autour d'un tel sujet". Tradução da autora. 


\section{Criação \&}

expressão do corpo), do pensamento, da prática, da interpretação de texto e da escritura. Se as palavras nada dizem, a verdade não existe. Que se afirme aquilo que nos impulsiona, que é pulsão, o prazer. Ou, nas palavras de Nietzsche:

Talvez então, sendo homens que riem, um dia mandem toda a consolação metafísica para o inferno - com a metafísica na frente! Ou, usando a linguagem desse monstro dionisíaco chamado Zaratustra: erguei vossos corações bem alto, meus irmãos! Mais alto! $E$ não esqueçais as pernas! Erguei também as pernas, ó bons dançarinos, e melhor ainda: ficai de cabeça para baixo! (NIETZSCHE, 2020, p. 18).

Assim, é evidente que se Barthes tivesse escrito seu romance Vita Nova, teria seguido o segundo tipo de programação indicado por Valéry, a saber, "pela mobília de uma grande forma fantasiada ('imaginária') e é nisso, por conseguinte, uma atividade mais estética do que lógica (que se pareceria mais com a de um pintor ou em todo caso de um grafista oriental que mobília um espaço)" (cf. nota 3). Porquanto, a arte dionisíaca é aquela responsável pela dissolução do "eu", pela unificação, por rejuntar o espaço deixado pela transcendência da criação, claramente muito mais estética do que lógica, em que se preenche um espaço com cores ou "mobília", que, cumpre dizer, leva tal nome graças à sua capacidade de movimentação (HOUAISS; VILLAR, 2001, p. 1938).

E para que seja preenchido o espaço, para que haja dança ou escritura, é necessário um fundo (palco ou papel) para que a imagem (espetáculo ou leitura) possa ser criada. Nesse sentido, pode-se dizer que se uma dançarina performa passos, as palavras performam frases. Não à toa, na seção de fragmentos dedicados à Frase em $O$ prazer do texto, Barthes encerra com uma declaração de Valéry:

De fato, é o poder de acabamento que define a maestria frásica e marca, como que de uma expertise suprema, custosamente adquirida, conquistada, os agentes da frase. [...] Valéry dizia: "não pensamos palavras, não pensamos senão frases". Ele o dizia porque era escritor. É dito escritor não aquele que exprime seu pensamento, sua paixão ou imaginação pelas frases, mas aquele que pensa frases: um PensaFrase (isso é: nem inteiramente um pensador, nem inteiramente um fraseador) ${ }^{17}$ (BARTHES, 1973b, p. 81).

\footnotetext{
17 "C'est en effet le pouvoir d'achèvement qui définit la maîtrise phrastique et marque, comme d'un savoir-faire suprême, chèrement acquis, conquis, les agents de la phrase. [...] Valéry disait: 'on ne pense pas des mots, on ne pense que des phrases'. II le disait parce qu'il était écrivain. Est dit écrivain, non pas celui qui exprime sa pensée, sa passion ou son imagination par des phrases, mais celui qui pense des phrases: un Pense-Phrase (c'est-à-dire: pas tout à fait un penseur, et pas tout à fait un phraseur)". Tradução da autora.
} 


\section{Criação \&}

Isso quer dizer que a arte de escrever no pensamento barthesiano não consiste em se exprimir através de frases, mas tão somente em pensá-las: as frases não são o veículo da expressão, mas sim a própria coisa, a própria expressão. Em outras palavras, a performance é o ato em si, não o simulacro de uma cena ideal, o que coincide com a concepção de texto de Valéry, que vê na poesia um artefato preciso destinado "a reproduzir, no leitor, um 'estado poético"', ou seja,

a sensação de que as coisas estão ligadas umas às outras, não se esgotam na pura percepção nem se circunscrevem ao mero conceito, à pura palavra que as denota. Há um estado de "conotação" absoluta, se podemos dizer assim, na poesia: a metáfora é apenas um dos artifícios retóricos capazes de evocá-la no leitor. Mas o principal mecanismo da literatura, da poesia, é para Valéry essa "oscilação" entre o som e o sentido, que faz do mero verbal de comunicação, da simples linguagem denotativa, uma forca capaz de superar seu caráter instrumental e transitivo, para criar harmonias sonoras e espessuras encantatórias, como se, por passe de mágica, a forma de um verso e o jogo de suas vogais e consoantes ganhasse a materialidade, a força edênica de uma "coisa". Não mais um sinal neutro da coisa que designa, mas a coisa ela mesma, a realidade palpável, o sabor, o contomo, o cristal e a came de nossas percepções (COELHO, 1996, p. 11-12).

De modo análogo, é isso o que se tem em O prazer do texto barthesiano: uma "oscilação", uma desestabilização que produz "espessuras" em que o jogo, a dança das palavras, ganha materialidade, causando prazer e assim possibilitando a leitura, a saber, a infindável construção de uma verdade autorreferenciada que nasce no prazer e a ele retorna, dissolvendo o sujeito ao reunir leitor e texto.

Texto quer dizer Tecido; mas eis que até aqui sempre se tomou esse tecido por um produto, um véu pronto, atrás do qual se tem, mais ou menos escondido, o sentido (a verdade), nós acentuamos agora, no tecido, a ideia generativa que o texto se produz, se trabalha através de um entrelaçado perpétuo; perdido nesse tecido - nessa textura - 0 sujeito se desfaz nela, como uma aranha que se dissolve a si mesma nas secreções constitutivas de sua teia ${ }^{18}$ (BARTHES, 1973b, p. 100-101).

\footnotetext{
18 "Texte veut dire Tissu; mais alors que jusqu'ici on a toujours pris ce tissu pour un produit, un voile tout fait, derrière lequel se tient, plus ou moins caché, le sens (la vérité), nous accentuons maintenant, dans le tissu, l'idée générative que le texte se fait, se travaille à travers un entrelacs perpétuel; perdu dans ce tissu - cette texture - le sujet s'y défait, telle une araignée qui se dissoudrait elle-même dans les sécrétions constructives de sa toile". Tradução da autora.
} 


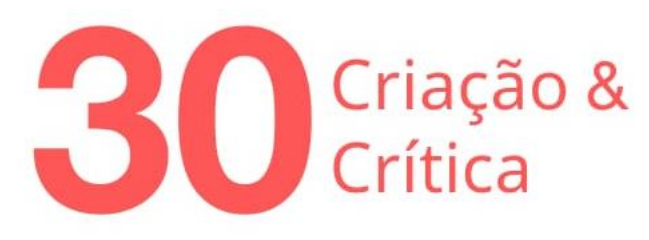

Ou seja, para que haja leitura do texto barthesiano, é preciso que seu leitor dance junto com ele, pois, ao tecer sua leitura, o sujeito se emaranha nas palavras e assim tece significado. Ou, nas palavras de Valéry, versando sobre as dançarinas:

\begin{abstract}
Suas mãos falam, e seus pés parece que escrevem. Que precisão nesses seres que se dedicam a usar tão bem de suas forças tenras! Todas as minhas dificuldades me desertam, e não há no presente algum problema que me ocupe, tanto obedeço com alegria à mobilidade dessas figuras! Aqui, a certeza é um jogo; dir-se-ia que o conhecimento encontrou seu ato, e que a inteligência de imediato consente às graças espontâneas... (VALÉRY, 1996, p. 24).
\end{abstract}

Mais precisamente, palavras de Valéry na boca de Sócrates, visto que tal fragmento constitui a fala de um personagem chamado Sócrates em sua versão de um diálogo platônico:

Platônico na forma, o diálogo de Valéry seria nietzschiano no conteúdo. Conhecem-se as violências de Nietzsche contra a atividade racional, e sua nostalgia pelo êxtase dionisíaco, pela dança generalizadora, embriagada, capaz de dissolver qualquer distinção entre $A$ e $B$, entre uma coisa e outra coisa, entre conceito e conceito (COELHO, 1996, p. 10-11).

Cumpre dizer que, assim como Pascal, Sócrates é figura polêmica no pensamento de Nietzsche - e também um mito na história da Filosofia, sendo tido por muitos como seu pai. Cícero, por exemplo, atribui-Ihe tal estatuto nas Tusculanas (2014, p. 395) ao dizer que ele teria sido o primeiro a convidar a Filosofia a descer do céu, instalando-a nas cidades e impondo-lhe o estudo da vida e dos costumes. E cumpre dizer que ele foi morto por isso, como conta a Apologia de Sócrates, de Platão, sentenciado por não reconhecer as divindades do Estado, por introduzir novas divindades e por corromper os bons costumes, numa rebeldia a seu modo similar a de Nietzsche e a de Barthes.

Mas é interessante notar o início da jornada socrática em busca do conhecimento: em um culto corriqueiro da religião pagã, um amigo de Sócrates fora consultar o oráculo de Delfos. Lá, a sacerdotisa Pítia, dionisiacamente embriagada e inspirada por Apolo, deu-lhe uma profecia em forma de metáfora que, como todas, é necessário interpretar. Quando indagada pelo homem mais sábio da cidade, o oráculo disse-Ihe que esse era Sócrates. O próprio, uma vez sabendo da profecia por seu amigo, não a compreendeu, pois julgava-se ignorante da causalidade das coisas, não podendo ser sábio, portanto. Não podendo o oráculo estar errado, o erro estaria antes em sua interpretação: foi assim que Sócrates compreendeu que a sabedoria da profecia, sua própria sabedoria, estava na subversão da sabedoria: era justamente 


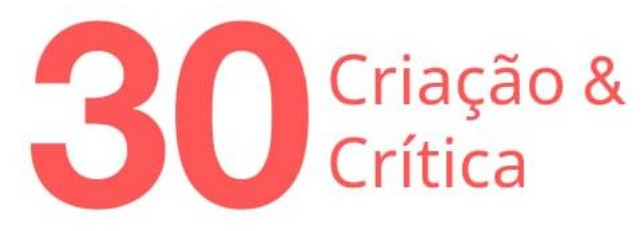

porque se reconhecia ignorante que era o mais sábio da cidade, dado que apenas quem reconhece que não sabe busca a sabedoria - eis a Filosofia, a filiação, o amor pela sabedoria, a busca do conhecimento (PLATÃO, 2008, 21d-e).

Fez ele de tal profecia sua missão: levar seus interlocutores à contradição para que se percebessem também ignorantes e buscassem o conhecimento, e assim nunca concebeu uma metafísica: sua forma de louvar a Filosofia era uma prática. Dialogava em praça pública com seus interlocutores, interrogando-os pela essência das coisas, fazendo com que caíssem em contradição, uma vez que, modernamente dizendo, os antigos também não viam pedra de toque entre significado e significante. Quando Sócrates Ihes perguntava o que era "a beleza", não faziam senão dar exemplos do que tomavam por belo, sempre tangenciando o belo, sem jamais penetrar em sua essência.

Se é possível dizer que tal problemática é uma herança que moveu a história da Filosofia até a contemporaneidade, pode-se também dizer que ela é um cheque sem fundo, tal qual a linguagem barthesiana herdeira de Nietzsche, de Pascal e de Sócrates, em que não se pode senão correr em círculos, como evoca a figura do ouroboro (a serpente que consome a própria cauda em eterno retorno ao seu começo), assim como as acepções de verdade de Nietzsche e Barthes, fadadas ao fracasso desde o início da história do pensamento ocidental, cujo desponte se deu com a profecia da sacerdotisa Pítia - nome esse, por sinal, derivado de pythia, serpente do grego (HOUAISS; VILLAR, 2001, p. 2229) -, por um acaso de ironia linguística, em que sabedoria e ignorância se confundem.

Ignorante, Sócrates jamais escreveu, o que é coerente com sua condição. Ora, Nietzsche dizia que "o melhor autor será aquele que tem vergonha de se tornar escritor" (2005b, p. 124). Nesse sentido, Barthes também era coerente em sua incoerência. Matou o autor e escrevia sobre escrever: não poderia ter escrito seu romance Vita Nova, pois, mesmo em busca de uma vida nova, ele, formado em Letras Clássicas, sabia que o abismo para o qual aponta a linguagem é tão profundo que se faz perder de vista seu fundo. Se a sabedoria nasceu morta, que se dance sobre seu túmulo: Barthes foi nietzschiano até morrer.

\section{Referências}

BARTHES, R. La préparation du roman. Cours au Collège de France (1978-1979 et 1979-1980). Paris: Éditions du Seuil, 2015.

BARTHES, R. Roland Barthes por Roland Barthes. São Paulo: Estação Liberdade, 2003.

BARTHES, R. Le plaisir du texte. Paris: Éditions du Seuil, 1973a.

BARTHES, R. Le lexique de l'auteur. Séminaire à l'Ecole pratique des hautes études (1973-1974). Paris: Éditions du Seuil, 1973b.

CíCERO, M, T. Discussões tusculanas. Uberlândia-MG: EDUFU, 2014.

COELHO, M. "Prefácio". In: VALÉRY, P. A Alma e a Dança e outros diálogos/Paul Valéry: apresentação e tradução, Marcelo Coelho. Rio de Janeiro: Imago, 1996. p. 9-13. 


\section{$30 \begin{gathered}\text { criacáo \& } \\ \text { critica }\end{gathered}$}

GIDE, A. La porte étroite. Paris: Gallimard, [s. d.].

HOUAISS, A.; VILLAR, M. Dicionário Houaiss da língua portuguesa. Rio de Janeiro: Objetiva, 2001.

LEBRETON, L. "Nietzsche, leitor de Pascal: "o único cristão lógico". Dissertatio, Pelotas, v. 48, p. 26-46, 2018.

NIETZSCHE, F. O nascimento da tragédia. São Paulo: Companhia das Letras, 2020. NIETZSCHE, F. Obras incompletas. São Paulo: Editora 34, 2014.

NIETZSCHE, F. Assim falou Zaratustra. São Paulo: Companhia das Letras, 2018. NIETZSCHE, F. Além do bem e do mal. São Paulo: Companhia das Letras, 2005a. NIETZSCHE, F. Humano, demasiado humano. São Paulo: Companhia das Letras, 2005b.

PASCAL, B. Pensées. Paris: Gallimard, 2000.

PERRONE-MOISÉS, L. Roland Barthes e o prazer da palavra. Disponível em: https://revistacult.uol.com.br/home/roland-barthes-e-o-prazer-da-palavral, 14 mar. 2010. Acesso em: 01 jul. 2021.

PINO, C. "Da filiação do pesquisador à filiação do escritor: Roland Barthes e o seminário da crise intelectual". Remate de Males, Campinas, v. 39, n. 2, p. 830-848, jul./dez. 2019.

PINO, C. "Viver, morrer e matar de escrever: os sacrifícios de Roland Barthes". Estudos: Linguísticos e Literários, Salvador, n. 42, p. 99-121, jul./dez. 2010.

PLATÃO. A Apologia de Sócrates. Porto Alegre: L\&PM, 2008.

VALÉRY, P. A Alma e a Dança e outros diálogos/Paul Valéry: apresentação e tradução, Marcelo Coelho. Rio de Janeiro: Imago, 1996.

WELLER, S. "Active Philology: Barthes and Nietzsche". French Studies, Oxford, v. 73, n. 2, p. 217-233, abr. 2019.

Recebido em: 03/04/2021 Aceito em: 05/07/2021

Referência eletrônica: NOJIRI, Julia Bunemer. As palavras dançantes de Barthes. Criação \& Crítica, n. 30, p., set. 2021. Disponível em: <http://revistas.usp.br/criacaoecritica>. Acesso em: dd mmm. aaaa. 